\title{
Pre-cecal Phosphorus Digestibility of Dicalcium Phosphate and Monocalcium Phosphate in Broilers
}

\author{
Pınar Saçaklı ${ }^{1, a, *}$, Özge Sızmaz ${ }^{1, b}$, Mahlagha Pirpanahi ${ }^{1, c}$ \\ ${ }^{1}$ Ankara University, Faculty of Veterinary Medicine Department of Animal Nutrition and Nutritional Disease, 06110 Ankara, Türkiye
} *Corresponding author

\begin{tabular}{|c|c|}
\hline A R T I C LE INFO & A B S T R A C T \\
\hline $\begin{array}{l}\text { Keywords: } \\
\text { Dicalcium Phosphate } \\
\text { Monocalcium Phosphate } \\
\text { Prececal digestibility }\end{array}$ & $\begin{array}{l}\text { The aim of this study was to determine the prececal phosphorus (P) digestibility of dicalcium } \\
\text { phosphate (DCP) and monocalcium phosphate (MCP) for broiler using the linear regression } \\
\text { method. A total of } 360 \text {-d-old male Ross } 308 \text { broilers were raised until } 20 \text { days of age with a } \\
\text { standard commercial starter diet (metabolizable energy, } 3000 \mathrm{kcal} / \mathrm{kg} \text {, crude protein, } 22 \% \text {, Ca } \\
0.9 \%, \mathrm{P} 0.6 \% \text { ). On } 21 \text { days of age all birds were weighed and assigned to } 5 \text { experimental treatment } \\
\text { groups with } 6 \text { replicate cages each consisted of } 12 \text { birds. Each P source was included at two levels } \\
\text { (to achieve increments of } 0.075 \% \text { and } 0.15 \% \text { ) to the basal diet. Titanium dioxide was included at } \\
0.5 \% \text { in all diets as indigestible marker. On day } 28 \text {, all birds were sacrificed and ileal digesta were } \\
\text { collected. The prececal P digestibility of DCP and MCP were calculated by the linear regression to } \\
\text { be } 76.60 \% \text { and } 85.83 \% \text {, respectively. The present results suggest that the P digestibility of the P } \\
\text { sources should be considered when formulating broiler diets to achieve optimum dietary P } \\
\text { concentrations without increasing diet cost and environmental pollution from P excretion. }\end{array}$ \\
\hline
\end{tabular}

Phosphorus

Broiler

Tavukçuluk Araştırma Dergisi 17(1): 22-26, 2020

\section{Dikalsiyum Fosfat ve Monokalsiyum Fosfatın Broylerlerde Presekal Fosfor Sindirilebilirliğinin Belirlenmesi}

\begin{tabular}{|c|c|c|}
\hline \multicolumn{2}{|c|}{ M A K A L E B İ L G İ S İ } & Ö Z \\
\hline \multicolumn{2}{|c|}{ Araştırma Makalesi } & $\begin{array}{l}\text { Bu çalışma dikalsiyum fosfat (DCP) ve monokalsiyum fosfatın (MCP) broylerde linear regresyon } \\
\text { metoduyla presekal fosfor sindirile bilirliğini belirlemek amaciyla gerçekleştirilmiştir. Denemede } \\
\text { toplam } 360 \text { adet bir günlük yaşta erkek broyler civciv (Ross 308) } 21 \text { günlük yaşa kadar standart } \\
\text { ticari brovler baslangıc vemi (Metabolize olabilir enerii } 3000 \mathrm{kcal} / \mathrm{kg} \text { ham protein } \% 22 \text { Ca } \% 0.9 \mathrm{P}\end{array}$ \\
\hline Geliş & $: 17 / 05 / 2020$ & $\% 0,6$ ) ile beslenmiștir. Broylerler 21 günlük yașta her biri 6 tekerrürden oluşan ve her tekerrürde 12 \\
\hline Kabul & : 10/06/2020 & $\begin{array}{l}\text { civciv bulunan } 5 \text { deneme grubuna ayrılmıştır. Fosfor sindirile bilirliği belirlenecek DCP ve MCP } \\
\text { bazal rasyona P düzeyini } \% 0,075 \text { ve } \% 0,15 \text { düzeylerinde artıracak oranda ilave edilmiştir. Markır } \\
\text { olarak titanyum dioksit } \% 0,5 \text { düzevinde kullanılmıstır. Denemenin } 28 \text { gününde fosfor sindirile }\end{array}$ \\
\hline \multirow{5}{*}{\multicolumn{2}{|c|}{$\begin{array}{l}\text { Anahtar Kelimeler: } \\
\text { Dikalsiyum fosfat } \\
\text { Monokalsiyum fosfat } \\
\text { Presekal sindirilebilirlik } \\
\text { Fosfor } \\
\text { Broyler }\end{array}$}} & bilirliğini belirlemek için bütün hayvanlardan ileum içeriği toplanmıştır. Linear regresyon \\
\hline & & metoduyla DCP ve MCP'nin presekal fosfor sindirile bilirlikleri sirasiyla $\% 76,60$ ve $\% 85,83$ olarak \\
\hline & & lanmıştır. Bu çalışma sonucunda broyler rasyonları formüle edilirken rasyon maliyetini ve \\
\hline & & $\begin{array}{l}\text { re kirliliğini artırmadan, optimum fosfor düzeylerinin ayarlanması için fosfor kaynaklarının } \\
\text { dirile bilirliklerinin bilinmesinin önemi vurgulanmıstır. }\end{array}$ \\
\hline & & \\
\hline
\end{tabular}




\section{Introduction}

Phosphorus (P) is a biologically essential mineral for poultry nutrition due to its important roles in optimum bone mineralisation, skeletal health and cellular metabolism (Suttle, 2010.). Plant feed ingredients such as cereal grains or meals which are major components used in poultry nutrition are rich in phosphorus. However, availability of phosphorus in plant ingredients is poor because of presenting in the form of phytic acid. Monogastric animals are not able to use more than twothird of plant based phosphorus due to lack of/not enough endogenous phytase activity (Selle and Ravindran, 2007). Therefore, commercially available inorganic phosphate sources such as monocalcium phosphate (MCP), monodicalcium phosphate (MDCP) and dicalcium phosphate (DCP) are widely added to poultry diets to ensure P requirement (Sauvant et al., 2004; Viljoen, 2001). But, inorganic phosphorus sources (phosphate rock) is a non-renewable resource (Leske and Coon, 2002). As world population grow drastically, phosphorus demand will increase due to the need to produce more animal protein sources.

Among of the different inorganic P sources, DCP and MCP are the most common used ingredients in poultry diets. The availability of $\mathrm{P}$ sources has been shown vary according to their source, molecular structure, age and species of the animals, diets composition such as Ca level, phytate in the plant ingredients etc. (Ammerman, 1995; Axe, 1998). In addition there is important differences with regard to $\mathrm{P}$ digestibility of ingredients according to various approach used to determine $\mathrm{P}$ digestibility. These differences may cause excessive or inadequate formulation of $\mathrm{P}$ level in the diets. Low $\mathrm{P}$ levels can depress growth performance of animals or high $\mathrm{P}$ levels can cause environmental pollution due to excessive $\mathrm{P}$ excreation (Lima, et al., 1997). Both economically and environmentally, optimum $\mathrm{P}$ formulation is very important for poultry diets. This requires adequate knowledge in the $\mathrm{P}$ digestibility and availability of different $\mathrm{P}$ ingredients.

In this study our aim was to determine prececal phosphorus ( $\mathrm{pcP}$ ) digestibility of $\mathrm{P}$ from two different inorganic $\mathrm{P}$ sources (DCP and MCP) according to currently considered as the preferable method which is developed the protocol by the (WPSA, 2013) for the determination of $\mathrm{P}$ digestibility.

\section{Materials and Methods}

Birds and Management: The experiment was conducted under the guidelines for animal care and use of Ankara University Ethic Commision (2019-19-179). A total of 360-d-old male Ross 308 broilers were obtained from a commercial hatchery (Beypiliç AŞ). The birds raised in floor pens $(200 \times 100 \mathrm{~cm})$ with wood shavings. Until 20 days of age the birds received a commercial starter diet (metabolizable energy, $3000 \mathrm{kcal} / \mathrm{kg}$, crude protein, $22 \%$, Ca $0.9 \%$, P $0.6 \%$ ). Feed and water were provided ad libitum. On 21 days of age birds were weighed and 360 birds assigned to 5 treatment groups with 6 replicate cages each consisted of 12 birds. Temperature was set at $34^{\circ} \mathrm{C}$ at d 1 and every week 3 or $4^{\circ} \mathrm{C}$ gradually reduced to $21^{\circ} \mathrm{C}$ at $\mathrm{d} 21$ and after which it remained constant. Lighting schedule was 24 L:OD and controlled during the experimental period. Feed and water were provided ad libitum during the complete period of the experiment.

Experimental diets: Dicalcium phosphate (DCP) and Monocalcium phosphate (MCP) (Greenphos DCP and Greenphos MCP BAF Premiks ve Tarım Sanayi ve Dış Ticaret Ltd. Şti.- Turkey) were used in the study. Main ingredients of experimental diets consist of corn, soybean meal, corn starch and dry egg albumen to achieve a low $\mathrm{P}$ concentration and low intrinsic phytase activity.

DCP and MCP as the test ingredients were included at 2 levels (4.2 and $8.3 \mathrm{~g} / \mathrm{kg} ; 3.3$ and $6.5 \mathrm{~g} / \mathrm{kg}$, respectively) into the basal diet to achieve of $\mathrm{P}$ content from test ingredients as 0.075 and $0.15 \%$ (Table 1 ).

Titanium dioxide $(0.5 \%)$ was added as an indigestible marker. Experimental diets were pelleted with $3 \mathrm{~mm}$ diameter without steam. The study followed the protocol developed by the (WPSA, 2013) for the determination of $\mathrm{P}$ digestibility.

\section{Data Collection}

Body weight gain (BWG) and feed intake (FI) were measured at 21 and 28 days of age. On day 28, all birds were sacrified. The ileum part between Meckel's diverticulum and $2 \mathrm{~cm}$ prior to the ileo-ceca-colonic junction dissected. The terminal $2 / 3$ of the section were obtained for digesta collection and this ileal contents were flushed with distilled water, pooled from all birds within a cage, immediately fozen at $-20^{\circ} \mathrm{C}$, and later digesta samples dried and ground.

\section{Physical and Chemical Analysis}

Samples of diet and ileal digesta were analysed for $\mathrm{DM}, \mathrm{Ca}$, total $\mathrm{P}$ and titanium. DM was determined by drying samples at $105^{\circ} \mathrm{C}$, for $8 \mathrm{~h}$ in an oven (AOAC, 2012). Ash was determined at $550^{\circ} \mathrm{C}$ for $6 \mathrm{~h}$ in a furnace (AOAC, 2012). Ca and P concentrations were determined by spectrophotometric method. Titanium was determined by the colorimetric method as described by (Brandt and Allam, 1987).

\section{Calculations}

The prececal $\mathrm{P}$ digestibility of test ingredients were calculated according to the procedures described by (WPSA, 2013). The ileal P digestibility (Pd) was calculated for each diet and replicate cage using the following equation:

$$
\mathrm{Pd}(\%)=100-\left[100 \times\left(\mathrm{TiO}_{2} \text { Diet } \mathrm{P}_{\text {Dig }}\right) /\left(\mathrm{TiO}_{2} \text { Dig } \times \mathrm{P}_{\text {Diet }}\right)\right]
$$

Where, $\mathrm{TiO}_{2}$ Diet, $\mathrm{TiO}_{2}$ Digesta is the marker concentration in the diet and ileal digesta samples, PDigesta (P Dig), P Diet is the P concentration in the diet and ileal digesta samples. All analysed values were expressed as grams per kilogram of DM. 


\section{Statistical Analysis}

The performance data (all dietary treatments) and $\mathrm{P}$ digestibility of experimental diets (each test ingredient) were analysed using analysis of variation. Significant differences among treatment groups were compared using the Duncan's new multiple range test function of SPSS (2016).
Mortality rates were compared using a chisquared test. Statistical differences were considered significant at $(\mathrm{P}<0.05)$. $\mathrm{P}$ digestibility of each test ingredient was calculated as described by (WPSA, 2013), using the linear regression model.

Table 1. Ingredient and nutrient composition ( $\mathrm{g} / \mathrm{kg}$ as Fed Basis) of experimental diets

\begin{tabular}{|c|c|c|c|c|c|}
\hline Ingredients & Basal diet & DCP $0.075 \%$ & DCP $0.15 \%$ & MCP $0.075 \%$ & MCP $0.15 \%$ \\
\hline Corn & 510 & 510 & 510 & 510 & 510 \\
\hline Soybean meal & 200 & 200 & 200 & 200 & 200 \\
\hline Corn starch & 142 & 142 & 141.2 & 142 & 141.5 \\
\hline Dried egg albumen & 100 & 100 & 100 & 100 & 100 \\
\hline Soy oil & 10 & 10 & 10 & 10 & 10 \\
\hline Vitamin Mineralmix $*$ & 5.0 & 5.0 & 5.0 & 5.0 & 5.0 \\
\hline Choline chloride & 0.8 & 0.8 & 0.8 & 0.8 & 0.8 \\
\hline Anticoccidial & 0.5 & 0.5 & 0.5 & 0.5 & 0.5 \\
\hline $\mathrm{NaCl}$ & 3.5 & 3.5 & 3.5 & 3.5 & 3.5 \\
\hline Lysine & 3.4 & 3.4 & 3.4 & 3.4 & 3.4 \\
\hline Methionine & 1.8 & 1.8 & 1.8 & 1.8 & 1.8 \\
\hline Threonine & 1.0 & 1.0 & 1.0 & 1.0 & 1.0 \\
\hline Titanium dioxide & 5.0 & 5.0 & 5.0 & 5.0 & 5.0 \\
\hline Limestone & 10 & 9.5 & 9.5 & 9.5 & 11 \\
\hline $\mathrm{DCP}$ & 0 & 4.2 & 8.3 & 0 & 0 \\
\hline MCP & 0 & 0 & 0 & 3.3 & 6.5 \\
\hline Silica & 7 & 3.3 & 0 & 4.2 & 0 \\
\hline Total & 1000 & 1000 & 1000 & 1000 & 1000 \\
\hline \multicolumn{6}{|c|}{ Nutrients calculated } \\
\hline Crude protein, $\%$ & 21.5 & 21.5 & 21.5 & 21.5 & 21.5 \\
\hline $\mathrm{ME}, \mathrm{kcal} / \mathrm{kg}$ & 3183 & 3183 & 3183 & 3183 & 3183 \\
\hline $\mathrm{Ca}, \%$ & 0.36 & 0.44 & 0.54 & 0.40 & 0.53 \\
\hline $\mathrm{tP}, \%$ & 0.27 & 0.35 & 0.42 & 0.34 & 0.42 \\
\hline
\end{tabular}

Content of vitamin and mineral premix provided per kg of diet: vitamin A, $15000 \mathrm{IU}$; vitamin D3, $5000 \mathrm{IU}$; vitamin, $50 \mathrm{mg}$; vitamin K3, $10 \mathrm{mg}$; vitamin B1, 4 $\mathrm{mg}$; vitamin B2, $8 \mathrm{mg}$; vitamin B6, 5mg; vitamin B12, 0.025mg; niacin, $50 \mathrm{mg}$; pantothenic acid, $20 \mathrm{mg}$; folic acid, $20 \mathrm{mg}$; biotin, $0.25 \mathrm{mg}$; manganese, 100 mg; zinc, $150 \mathrm{mg}$; iron, $100 \mathrm{mg}$; cupper, $20 \mathrm{mg}$; iodine, $1.5 \mathrm{mg}$; cobalt, $0.5 \mathrm{mg}$; selenium, $0.2 \mathrm{mg}$; molybdenum, 1mg; magnesium, $50 \mathrm{mg}$.

Table 2. Growth performance and prececal phosphorus digestibility of greenphos dcp and mcp of birds fed experimental diets, 21-28 days of age ( $\mathrm{n}=12$ Broilers Per Treatment)

\begin{tabular}{|c|c|c|c|c|c|c|c|}
\hline Parameters & Basal diet & $\begin{array}{c}\text { DCP } \\
0.075 \%\end{array}$ & $\begin{array}{c}\text { DCP } \\
0.15 \%\end{array}$ & $\begin{array}{c}\text { MCP } \\
0.075 \%\end{array}$ & $\begin{array}{c}\mathrm{MCP} \\
0.15 \%\end{array}$ & SEM & P-value \\
\hline Body weight, d 21 (g) & 1040 & 1012 & 1038 & 1010 & 1011 & 18.85 & 0.974 \\
\hline Body weight, d 28 (g) & 1371 & 1509 & 1576 & 1515 & 1566 & 24.95 & 0.057 \\
\hline Body weight gain, 21-28 d (g) & $330^{\mathrm{b}}$ & $497^{\mathrm{a}}$ & $538^{a}$ & $488^{\mathrm{a}}$ & $555^{\mathrm{a}}$ & 17.80 & $<0.001$ \\
\hline Feed intake $21-28 \mathrm{~d}(\mathrm{~g})$ & $480^{\mathrm{b}}$ & $665^{\mathrm{a}}$ & $728^{a}$ & $680^{\mathrm{a}}$ & $756^{\mathrm{a}}$ & 22.55 & $<0.001$ \\
\hline FCR, Feed intake/weight gain & 1.461 & 1.340 & 1.360 & 1.352 & 1.374 & 0.027 & 0.669 \\
\hline Mortality \% & 0 & 0 & 1.4 & 0 & 1.4 & & 0.555 \\
\hline $\mathrm{tP}, \mathrm{g} / \mathrm{kg} \mathrm{DM}$ & 2.37 & 2.87 & 3.65 & 3.20 & 4.30 & & \\
\hline $\mathrm{P}$ digestibility*, \% & 67.51 & 76.65 & 71.50 & 87.5 & 76.74 & - & - \\
\hline pcP digestibility**, $\mathrm{g} / \mathrm{kg}$ & 1.60 & 2.20 & 2.61 & 2.80 & 3.30 & - & - \\
\hline
\end{tabular}

DCP: Dicalcium phosphate, MCP: Monocalcium phosphate, FCR: Feed conversion ratio, tP: Total phosphorus, pcP: Prececal phosphorus digestibility, *Phosphorus digestibility values were obtained from regression analysis (Figure 1 and 2) and **pcdP values of the diet were calculated according to this $\mathrm{P}$ digestibility values

\section{Results and Discussion}

Nowadays, economical and ecofriendly livestock production issues become more important than in the past. Phosphorus is the ingredient focused on in this issue. Therefore, ensuring optimum $\mathrm{P}$ level in broiler diets is big challenge for the industry. Many studies (Leske and Coon, 2002; Waldroup, 1999; Yan and Waldroup, 2006) demostrates that (NRC, 1994) recommendations for $\mathrm{P}$ requirement of broilers is much higher than actual need of the animal. The greatest challenge in optimizing $\mathrm{P}$ level is the digestibility and bioavailability of different inorganic $\mathrm{P}$ sources. There are some measurements of bioavailability of $\mathrm{P}$ such as weight gain, blood parameters, tibia breaking strength, tibia and toe ash. All these parameters have been used for bioassays to measure the in vivo bioavailability of this mineral.

The results of the present study showed that the body weight gain and total feed intake during 21-28 days were significantly higher for birds fed with the test diets 
compared to the basal diet. Body weight and FCR were improved by the addition of inorganic $\mathrm{P}$ sources but, there is no statistical difference among the groups (Table 2). During the experimental period only 2 birds died one of from DCP and one of from MCP groups. As seen in Table 2 the total $\mathrm{P}$ concentration had a significant $(\mathrm{P}<0.001)$ effect on BWG and FI during 21-28d of age. Birds fed with the diet having the lowest prececal digestible $\mathrm{P}$ (pcdP; g/kg) had lower BWG at d 28 and lower FI compared to birds fed with pcdP concentrations ranging from 1.60 to $3.30 \mathrm{~g} / \mathrm{kg}$. No differences in BW and FCR were observed between the diets with different pcdP concentrations. Smilarly, (Leske and Coon, 2002; Yan and Waldroup; 2006; Mello et al., 2012; Bikker et al., 2016) found that negative effect of the diets containing low $\mathrm{P}$ levels on growth performance. There was no differences between $\mathrm{P}$ sources (either DCP or MCP). Main effect resulted from $\mathrm{P}$ concentration. However, pcP digestibility of MCP was higher than that of DCP. Chemical composition of the $\mathrm{P}$ sources caused this difference.

In our study pcP digestibilities of DCP and $\mathrm{MCP}$ were found as $76.60 \%$ and $85.83 \%$, respectively. These results higher than those of the some literatures (Shastak et al., 2012; Van der Klis and Versteegh, 1992) for DCP and MCP (Rodehutscord et al., 2012).

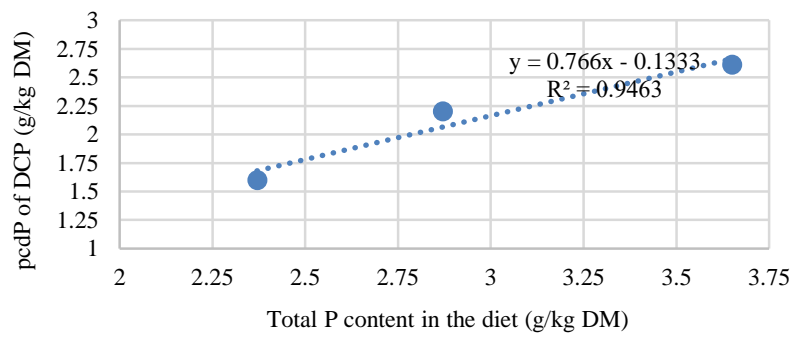

Figure 1. Pre-cecal Phosphorus Digestibility of DCP

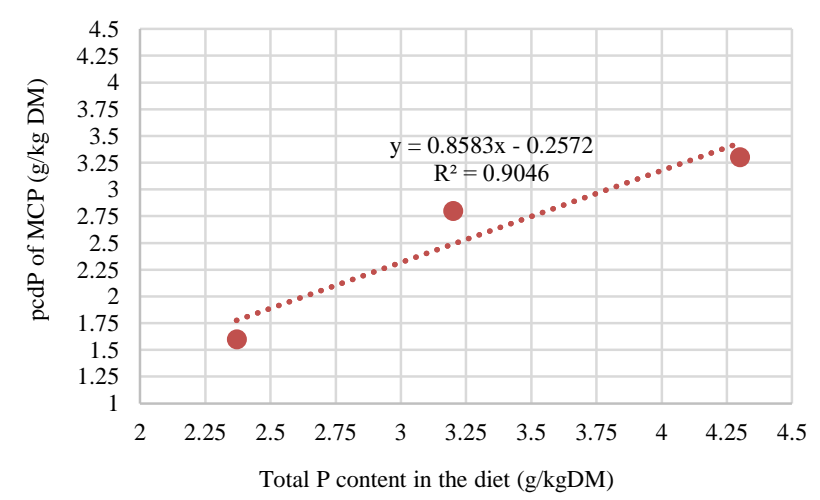

Figure 2. Pre-cecal Phosphorus Digestibility of MC

Ketels and De Groote, (1988) reported pcP digestibility of anhydrose DCP and DCP $+\mathrm{H} 2 \mathrm{O}$ to be $67 \%$ and $73 \%$, respectively. DCP used in our experiment was hydrate DCP and the P digestibility was similar. (Van der Klis and Versteegh, 1996) showed P retention levels of $92 \%$ for $\mathrm{MCP}+\mathrm{H} 2 \mathrm{O}$ and $55 \%$ for anhydrose DCP. These values were lower than our result for DCP and higher for MCP. There are highly differences on $\mathrm{P}$ digestibility of MCP in the literature with $45 \%$ to $88 \%$ (Bikker et al., 2016; Rodehutscord et al., 2012; Van Harn et al; 2017) and DCP with $25 \%$ to $82.4 \%$ (Bikker et al., 2016; Shastak et al., 2012) These discrepancies between digestibility values might be resulted from differences in methodologies, animal age, basal diet, source of $\mathrm{P}$, diet $\mathrm{Ca}, \mathrm{P}$ level and $\mathrm{Ca}: \mathrm{P}$ ratio. It is known that $\mathrm{P}$ digestibility from hydrose sources of DCP or MCP higher than that of anhydrose forms (De Groote and Lippens, 2002).

Another factor that affect $\mathrm{P}$ digestibility is particle size of phosphate source. Phosphate sources with larger particle size have more biologic availability because of longer retaining in the gizzard to be complete digestion.

\section{Conclusion}

As a conclusion, $\mathrm{P}$ level and bioavailability have important effect on growth performance, diet cost and environmental pollution. There are big differences in $\mathrm{P}$ digestibility values. While comparing phosphorus sources and including to the broiler diets digestibility values and the methods that used for assesment should be considered.

\section{References}

Ammerman, C.B., 1995. Methods for Estimation of Mineral Bioavailability. "Eds. C.B. Ammerman, D.H. Baker, A.J. Lewis, Bioavailability of Nutrients for Animals: Amino Acids, Minerals, and Vitamins, pages: 83-94, Academic Press Inc. San Diego CA.

AOAC, 2012. Official Methods of Analysis of AOAC International. AOAC International. Washington DC.

Axe, D., 1998. Phosphorus Value in İngredient Sources Examined. Feedstuffs 70:17-28.

Bıkker, P., Spek, J.W., Van Emous, R.A., Van Krımpen, M.M., 2016. Precaecal Phosphorus Digestibility of İnorganic Phosphate Sources in Male Broilers. British Poultry Science 57(6):810-817.

Brandt, M., Allam, SM., 1987. Analytik Von TiO2 Im Darminhalt Und Kotnach Kjeldahl Aufschlub. Arch. Anim Nutr. 37:453-454.

De Groote, G., Lippens, M., 2002. Phosphorus Bioavailability for Poultry. "Eds. A.W. Jongbloed, P.A. Kemme, G. De Groote, M. Lippens, F. Meschy, Bioavailability of Major and Trace Elements, Pages:43-48 EMFEMA Brussels Belgium.

Ketels, E., G. De Groote., 1988. The Relative Bioavailability and The Ileal Digestibility of Phosphorus in Mineral and Animal Sources. 18th World's Poultry Congress 1998. Japan Poultry Science Association, Nagoya, Japan. 873-874.

Leske, K., Coon, C.N., 2002. The Development of Feedstuff Retainable Phosphorus Values For Broilers. Poult. Sci. 81:1681-1693.

Lima, F.R., Mendonca, C.X. Jr., Alvarez, J.C., Garzillo, J.M.F., Ghion, E., Leal, P.M., 1997. Biological Evaluations of Commercial Dicalcium Phosphates as Sources of Available Phosphorus For Broiler Chicks. Poult. Sci. 76:1707-1713.

Mello, H.H.C., Gomes, P.C., Rostagno, H.S., Albıno, L.F.T., Da Rocha, T.C., De Almeıda, R.L., Calderano, A.A., 2012. Dietary Requirements of Available Phosphorus in Growing Broiler Chickens at A Constant Calcium: Available Phosphorus Ratio. Revista Brasileira de Zootecnia 41:2323-2328.

NRC. 1994. Nutrient Requirements of Poultry, 9th ed. National Academy Press. Washington DC.

Pesti, G.M., Bakalli, R.I., Driver, J.P., Atencio, A., Foster, E.H., 2005. Poultry Nutrition and Feeding (A Textbook). Trafford. Victoria. 
Rodehutscord, M., Dieckmann, A., Witzig, M., Shastak, Y. 2012. A Note on Sampling Digesta From The İleum of Broilers in Phosphorus Digestibility Studies. Poult. Sci. 91:965-971.

Sauvant, D., Perez, J.M., Tran, G., 2004. Tables of Composition and Nutritional Value of Feed Materials: Pigs, Poultry, Cattle, Sheep, Goats, Rabbits, Horses and Fish. Wageningen Academic Publishers. Wageningen.

Selle, P.H., Ravindran, V., 2007. Microbial Phytase in Poultry Nutrition. Anim. Feed Sci. Technol. 135:1-41.

Shastak, Y., Witzig, M., Hartung, K., Rodehutscord, M., 2012. Comparison of Retention and Prececal Digestibility Measurements in Evaluating Mineral Phosphorus Sources in Broilers. Poult. Sci. 91:2201-2209.

Suttle, N.F., 2010. Mineral Nutrition of Livestock, 4th ed. CABI. Publishing, CAB International, Wallingford.

Van der Klis, J.D., H.A.J. Versteegh., 1996. Phosphorus Nutrition of Poultry. "Eds. P.C. Garnsworthy, J. Wiseman, W. Haresign, Recent Advances in Animal Nutrition, pages:71-83, Nottingham Univ. Press Nottingham UK.

Van der Klis, J.D., Versteegh H.A.J., 1993. The Availability of Phosphorus from Windmill Dicalphos for Broilers. Report No. 164. COVP-DLO, the Netherlands.
Van der Klis, J.D., Versteegh, H.A.J., 1992. De Beschikbaarheid Van Fosfor Foor Slachtkuikens İn Plantaardige En Dierlijke Veevoedergrondstoffen En İn Voederfosfaten. Verslag No. 132. COVP-DLO, the Netherlands.

Van Harn, J., Spek, J.W., Van Vuure, C. A., Van Krimpen, M.M., 2017. Determination of Pre-cecal Phosphorus Digestibility of İnorganic Phosphates and Bone Meal Products in Broilers. Poultry Science 96: 1334-1340.

Viljoen, J., 2001. Quality of Feed Phosphate Supplements for Animal Nutrition. South African Animal Science 2(1):1319.

Waldroup, P.W., 1999. Nutritional Approaches to Reducing Phosphorus Excretion by Poultry. Poult. Sci. 78: 683-691.

WPSA, 2013. Determination of Phosphorus Availability in Poultry. World's Poult. Sci. J. 69:687-698.

Yan, F., Waldroup, P.W., 2006. Non-phytate Phosphorus Requirement and Phosphorus Excretion of Broiler Chicks Fed Diets Composed Normal or High Available Phosphate Corn as İnfluenced by Phytase Supplementation and Vitamin D Source. Int. J. Poult. Sci. 5: 219-228 